\title{
YIELD OF COTTON/COWPEA AND SUNFLOWER/COWPEA CROP ROTATION SYSTEMS DURING THE RECLAMATION PROCESS OF A SALINE-SODIC SOIL
}

\section{CARLOS H. C. DE SOUSA ${ }^{1}$, CLAUDIVAN F. DE LACERDA ${ }^{2}$, FRANCISCO L. B. DA SILVA ${ }^{3}$, ANTONIA L. R. NEVES ${ }^{4}$, RAIMUNDO N. T. COSTA $^{5}$, HANS R. GHEYI ${ }^{6}$}

\begin{abstract}
The objective of this study was to evaluate the use of subsoiling, gypsum and organic matter associated with the cultivation of cotton, sunflower and cowpea in crop rotation, seeking the reclamation and use of a saline-sodic soil. The treatments were arranged in a randomized block design in split plots with four replications, during two crop cycles (2009/2010 and 2010/2011). The plots were formed by the treatments: T1. Subsoiling (S); T2. S $+20 \mathrm{Mg} \mathrm{ha}^{-1}$ of gypsum; T3. S + 40 $\mathrm{Mg} \mathrm{ha}^{-1}$ of organic matter; $\mathrm{T} 4 . \mathrm{S}+10 \mathrm{Mg} \mathrm{ha}^{-1}$ of gypsum $+20 \mathrm{Mg} \mathrm{ha}^{-1}$ of organic matter; $\mathrm{T} 5 . \mathrm{S}+$ $20 \mathrm{Mg} \mathrm{ha}^{-1}$ of gypsum $+40 \mathrm{Mg} \mathrm{ha}^{-1}$ of organic matter and the sub-plots consisted of the cottoncowpea $(\mathrm{C} / \mathrm{CP})$ and sunflower-cowpea $(\mathrm{S} / \mathrm{CP})$ crop rotation. The use of gypsum and organic matter contributed to decrease the soil salinity and sodicity. Cotton was not affected by the treatments, while the sunflower crop was favored by the application of amendments only in the second production cycle. Higher yields of cowpea in T5 treatment, during the 2009/2010 cycle, are indicative that higher doses of gypsum and organic matter applied in this treatment accelerate the reclamation process. For other treatments with amendment application there was a beneficial effect for this crop only in the second cycle, when the values of productivity were similar to T5.
\end{abstract}

KEYWORDS : salinity, sodicity, Gossypium hirsutum, Helianthus annuus, Vigna unguiculata

\section{PRODUTIVIDADE DE SISTEMAS DE ROTAÇÃO ALGODÃO/ FEIJÃO-DE-CORDA E GIRASSOL/ FEIJÃO-DE-CORDA DURANTE O PROCESSO DE RECUPERAÇÃO DE UM SOLO SALINO-SÓDICO}

RESUMO: O objetivo deste trabalho foi avaliar o uso de subsolagem, gesso agrícola e matéria orgânica, associados ao cultivo de algodão, girassol e feijão-de-corda em sistemas de rotação, visando à recuperação e o aproveitamento de um solo salino-sódico. Os tratamentos foram dispostos em um delineamento em blocos casualizados, em parcelas subdivididas, com quatro repetições, durante dois ciclos. As parcelas foram formadas pelos tratamentos: T1. Subsolagem (S); T2. S + 20 $\mathrm{Mg} \mathrm{ha}^{-1}$ de gesso (G); T3. S + $40 \mathrm{Mg} \mathrm{ha}^{-1}$ de matéria orgânica (MO); T4. S + $10 \mathrm{Mg} \mathrm{ha}^{-1}$ de G + 20 $\mathrm{Mg} \mathrm{ha}^{-1}$ de MO; T5. S + $20 \mathrm{Mg} \mathrm{ha}^{-1} \mathrm{de} \mathrm{G}+40 \mathrm{Mg} \mathrm{ha}^{-1}$ de $\mathrm{MO}$, e as subparcelas corresponderam às rotações culturais algodão feijão-de-corda (AL/FC) e girassol feijão-de-corda (GI/FC). O emprego dos corretivos contribuiu para a diminuição dos níveis de salinidade e sodicidade do solo. $\mathrm{O}$ algodão não apresentou nenhuma resposta à aplicação dos tratamentos, enquanto a cultura do girassol foi favorecida pela aplicação de corretivos apenas no segundo ciclo. As maiores produtividades do feijão-de-corda no tratamento T5, no ciclo de 2009/2010, são indicativos de que as maiores doses de gesso e de matéria orgânica aplicadas neste tratamento aceleraram o processo de recuperação. Para os demais tratamentos com corretivos, verificou-se efeito benéfico para essa cultura apenas no segundo ciclo de produção, quando os valores se igualaram ao T5.

PALAVRAS-CHAVE: salinidade, sodicidade, Gossypium hirsutum, Helianthus annuus, Vigna unguiculata

\footnotetext{
${ }^{1}$ Tecnólogo em Recursos Hídricos/Irrigação, Dr. Depto. de Eng. Agrícola, UFC/Fortaleza - CE, Fone: (85) 33669127, e-mail: sousaibiapina@yahoo.com.br;

2 Eng ${ }^{\circ}$ Agrônomo, Prof. Dr. Departamento de Engenharia Agrícola, UFC/Fortaleza - CE, e-mail:cfeitosa@ufc.br;

${ }^{3}$ Eng $^{\circ}$ Agrônomo, Doutorando do Departamento de Engenharia Agrícola, UFC/Fortaleza - CE, e-mail: leandrocmid@yahoo.com.br;

${ }^{4}$ Tecnóloga em Recursos Hídricos/Irrigação, Dra ${ }^{a}$ Depto. de Eng. Agrícola, UFC/Fortaleza - CE. e-mail:leilaneves7@ hotmail.com;

5 Eng ${ }^{\circ}$ Agrônomo, Prof. Dr. Departamento de Engenharia Agrícola, UFC/Fortaleza - CE, e-mail: rntcosta@ufc.br;

${ }^{6}$ Eng $^{\circ}$ Agrônomo, Prof. Dr. Núcleo de Engenharia de Água e Solo, UFRB/Cruz das Almas - BA. e-mail: hans@pq.cnpq.br.

Recebido pelo Conselho Editorial em: 10-7-2012

Aprovado pelo Conselho Editorial em: 26-3-2014
}

Eng. Agríc., Jaboticabal, v.34, n.5, p. 867-876, set./out. 2014 


\section{INTRODUCTION}

The problem of soil salinization and sodification are among the main causes of environmental degradation (LV et al, 2008; ASHRAF, 2009; SOUSA et al, 2011) and it has increased worldwide, especially in arid and semi-arid regions, due to unfavorable weather conditions and inadequate irrigation management (LEAL et al., 2008). According to SMEDEMA \& SHIATI (2002) under irrigated conditions, even in a conservationist vision, three to five tons of salts are added per hectare per year, in the dry regions of the globe.

Salts that prevail in arid and semiarid regions are formed by the cations calcium, magnesium, sodium and potassium and the anions chloride, sulphate, carbonate and bicarbonate. Depending on the total salt concentrations and distribution between the cations and anions quoted, the saline soils formed may exhibit different characteristics in terms of morphology and physicochemical properties, reflecting on their productive potential. This fact is evidenced mainly by the predominance of sodium salts in the environment (MIRANDA et al., 2008).

The saline-sodic and sodic soils, with elevated levels of soluble salts and / or exchangeable sodium, are capable of reducing significantly the development and, consequently, the productivity of crops ( SILVEIRA et al., 2008; BARROS et al., 2009). These soils should not only be reclaimed by washing. In these types of soils it is necessary to incorporate chemical amendment calcium based or not, but by the reactions which produces calcium, in order to replace the sodium on the exchange complex and transfer it to the soil solution. When transferred to soil solution, sodium is in soluble form, when the leaching process may occur (RIBEIRO et al, 2009; MIRANDA et al, 2011). In this sense, the reclamation of sodic and saline-sodic soils aims to turn them into saline soils and then in normal or non-saline soils, not offering risk of salts to the point of severely impair seed germination, the growth and the production of crops (LEITE et al., 2007).

Several amendments offer alternatives for reclamation of soil with excess exchangeable sodium. Correctives as gypsum, sulfur, aluminum sulfate, calcium chloride and sulfuric acid; however, gypsum is the product most commonly used because of its low cost and abundance that is found in most parts of the world (MELO et al., 2008).

On the other hand, in addition to chemical conditioners or improvers, for example gypsum, the incorporation of organic materials, has been recommended such as: : cattle manure, green manure (CAVALCANTE et al., 2010.), urban waste compost (GALBIATTI et al., 2007) and distilleries residue to improve the permeability of sodic and saline-sodic soils. Authors like MURTAZA et al. (2006) agree that the use of organic matter and the leguminous crops have also shown good results, both for crop development as well as for the process of improving the hydrophysical characteristics of these soils.

The addition of manure, crop residues and organic industrial waste in the soil as well as use of sub soiling, can improve many aspects of a degraded soil by salts and sodium, such as water infiltration into the soil (CAVALCANTE et al., 2010). On the other hand, the use of crop rotation results in several improvements in the soil properties and is also recommended for saline environments, particularly when crops with varying degrees of salinity tolerance (MURTAZA et al, 2006;. (BEZERRA et al., 2010; LACERDA et al, 2011) are used.

Therefore, according to the context presented, the aim of this research was to study the use of sub soiling, gypsum and organic matter associated with the cultivation of cotton, sunflower and cowpea in rotation systems, aimed the reclamation and utilization of saline-sodic soil.

\section{MATERIAL AND METHODS}

The study was conducted on family farm located in Nucleus A of the Irrigated area at Curu Pentecoste, in the municipality of Pentecoste $\left(3^{\circ} 40^{\prime} \mathrm{S}, 39^{\circ} 15^{\prime} \mathrm{W}, 150 \mathrm{~m}\right.$ of altitude), Ceará, Brazil. The perimeter extends to the banks of the Curu River and their affluents Caninde and Caxitoré, encompassing a total area of 4,569.39 ha and 984.00 ha equipped with irrigation infrastructure and 
the remainder destined to the rainfed areas or areas not suitable for agriculture for several reasons. According to Köppen, the experimental area is located in a region of climate type BSw'h' (semiarid). During the conduction of the study, there was a total precipitation of $1,479 \mathrm{~mm}$, being 413 $\mathrm{mm}$ in 2010 and $1,066 \mathrm{~mm}$ in 2011.

In August 2009, before the installation of the crops, the cleaning and the deepening to 1.35 $\mathrm{m}$ of the collector drain in the area was performed. The installation of a underground drainage system consisting of 10 lines of drainage tubes with a diameter of $65 \mathrm{~mm}$ wrapped in blanket bidim OP 20 and a gravel box $\mathrm{N}^{\circ} 1$ was also performed. The depth at the beginning of the collector drain was $1.45 \mathrm{~m}$ and for the underground drainage system was $1.10 \mathrm{~m}$. The slopes used in the collector drain and for the underground drainage line system were respectively $0.15 \%$ and $0.30 \%$ taking into account the depth of the main drain of Perimeter, which at its base was $1.85 \mathrm{~m}$ to establish the depths of the installation system.

The operation of setting the experiment began in August 2009 and was composed of a sub soiling to a depth of $0.60 \mathrm{~m}$, two disking and a systematization aiming to facilitate irrigations and maintain uniformity of water movement. The experiment was conducted in randomized block, in split plot design with four replications. The plots were formed by chemical and organic treatments and the subplots corresponded to the cotton-cowpea (C/CP) and sunflower-cowpea (S/CP) crop rotation. The whole area of the experiment received a sub soiling with the purpose of breaking the compacted and impermeable layer to water flow in the soil profile. The treatments were studied in plots:

T1. Control- just sub soiling (S);

T2. Sub soiling $+20 \mathrm{Mg} \mathrm{ha}^{-1}$ of gypsum $\left(\mathrm{SG}_{20}\right)$;

T3. Sub soiling $+40 \mathrm{Mg} \mathrm{ha}^{-1}$ of organic matter $\left(\mathrm{SOM}_{40}\right)$;

T4. Sub soiling + $10 \mathrm{Mg} \mathrm{ha}^{-1}$ of gypsum $+20 \mathrm{Mg} \mathrm{ha}^{-1}$ organic matter $\left(\mathrm{SG}_{10} \mathrm{OM}_{20}\right)$;

T5. Sub soiling $+20 \mathrm{Mg} \mathrm{ha}^{-1}$ of gypsum $+40 \mathrm{Mg} \mathrm{ha}^{-1}$ of organic matter $\left(\mathrm{SG}_{20} \mathrm{OM}_{40}\right)$.

The application of gypsum and organic matter was done after the preparation of the area, and the rates of gypsum $\mathrm{T} 2\left(\mathrm{SG}_{20}\right)$ and $\mathrm{T} 5\left(\mathrm{SG}_{20} \mathrm{OM}_{40}\right)$ were calculated according to CAVALCANTE et al. (2010), based on the data given in Table 1 and a depth of $0.30 \mathrm{~m}$. The dose of gypsum for the treatment $\mathrm{T} 4\left(\mathrm{SG}_{10} \mathrm{OM}_{20}\right)$ corresponded to $50 \%$ of the gypsum requirement. The applications of gypsum and organic matter were made by distributing amendments on soil surface, soon after the installation of the drainage system and the incorporation was made with the use of disc plows.

Each plot had the dimensions of $6.4 \mathrm{~m}$ wide and $20 \mathrm{~m}$ in length, corresponding to an area of $128 \mathrm{~m}^{2}$. Each sub plot had dimensions of $6.4 \mathrm{~m}$ wide by $10 \mathrm{~m}$ long, corresponding to an area of 64 $\mathrm{m}^{2}$ each containing 8 rows of planting of $10 \mathrm{~m}$.

The first crop occurred between September 2009 and January 2010 (dry season) using cottonseed (Gossypium hirsutum L.) cv. BRS 187 8H and sunflower (Helianthus annuus L.) cv. Catissol. The second planting occurred from September 2010 to January 2011 (dry season), using the same species. Planting took place at a spacing of $0.80 \mathrm{~m}$ between rows for the two species, and the spacing of $0.30 \mathrm{~m}$ between plants. At the end of cycle 10 plants per subplot were harvested to evaluate the productivity of cotton (seeds and plume) and sunflower seeds (achenes).

During the rainy seasons of 2010 and 2011 cowpea (Vigna unguiculata L. Walp.), cultivar EPACE 10, was cultivated, using the same spacing between rows and between plants of cotton and sunflower $(0.80 \times 0.30 \mathrm{~m})$, with two plants per hole. At the end of each cycle, around 70 days after sowing, the productivity evaluation was carried out, and then the crop residues were incorporated in soil.

Irrigation was performed through open furrows, and in the dry season crops (cotton and sunflower), the frequency was weekly according to water availability in the Perimeter, following 
technical recommendation for furrow irrigation. For the cowpea crop only supplemental irrigation was used, especially in 2010, due to lower rainfall that year. The water used in irrigation came from General Sampaio reservoir, distributed on the perimeter through a secondary channel, with the following chemical characteristics: $\mathrm{pH}=7.1 ; \mathrm{EC}=0.65 \mathrm{dS} \mathrm{m}^{-1} ; \mathrm{SAR}=1.83\left(\mathrm{mmol} \mathrm{L}^{-1}\right)^{1 / 2}$ and $1.29 ; 1.82 ; 2.29 ; 2.01$; and 3.52 mmol $_{\mathrm{c}} \mathrm{L}^{-1}$ of $\mathrm{Ca}^{2+}, \mathrm{Mg}^{2}, \mathrm{Na}^{+}, \mathrm{HCO}_{3}^{-}$and $\mathrm{Cl}^{-}$, respectively.

The characterization of the physical and chemical attributes of the soil, in the $0-0.30 \mathrm{~m}$ layer, was held in August 2009, before the start of the study, being the average data presented in Table 1. In July 2010 (after the first cycle of crop rotation and the passage of the rainy season) and in July 2011 (after the second cycle of crop rotation and the passage of the second rainy season) new composite samples per subplot were collected in the same layer to perform the chemical analysis.

TABLE 1. Mean values of physical and chemical properties of the soil prior to installation of the experiment in the $0-0,30 \mathrm{~m}$ layer.

\begin{tabular}{ccc}
\hline Attributes & Units & Values \\
\hline Textural class & & Sandy loam \\
$\mathrm{Sd}$ & $\mathrm{kg} \mathrm{dm}^{-3}$ & 1.41 \\
$\mathrm{Pd}$ & $\mathrm{kg} \mathrm{dm}^{-3}$ & 2.6 \\
Vw in $0,033 \mathrm{MPa}$ & $\mathrm{m} \mathrm{m}^{3} \mathrm{~m}^{-3}$ & 0.22 \\
Vw in $1,5 \mathrm{MPa}$ & $\mathrm{m}^{3} \mathrm{~m}^{-3}$ & 0.09 \\
$\mathrm{Ca}^{2+}$ & $\mathrm{cmol}_{\mathrm{c}} \mathrm{dm}^{-3}$ & 5.50 \\
$\mathrm{Mg}^{2+}$ & $\mathrm{cmol}_{\mathrm{c}} \mathrm{dm}^{-3}$ & 1.60 \\
$\mathrm{~K}^{+}$ & $\mathrm{cmol}_{\mathrm{c}} \mathrm{dm}^{-3}$ & 0.18 \\
$\mathrm{Na}^{+}$ & $\mathrm{cmol}_{\mathrm{c}} \mathrm{dm}^{-3}$ & 3.44 \\
$\mathrm{H}^{+}+\mathrm{Al}^{3+}$ & $\mathrm{cmol}_{\mathrm{c}} \mathrm{dm}^{-3}$ & 0.0 \\
$\mathrm{pH}$ in water $(1: 2,5)$ & & 8.0 \\
$\mathrm{EC}$ & & 4.0 \\
ESP & $\mathrm{dS} \mathrm{m}_{1: 1}^{-1}$ & 32.1 \\
\hline
\end{tabular}

Sd - soil density; Pd - particle density; Vw - volumetric water content; EC 1:1 - soil electrical conductivity measured in the extract 1:1 (soil: water); ESP - exchangeable sodium percentage

During the study chemical analysis of water samples from drains were performed. These samples were collected in January, July and December 2010 and in June 2011 for the determination of sodium, potassium concentrations by flame photometry and calcium absorption by atomic spectrophotometry.

The results of the variables related to soil, drainage water and the productivity of the species were subjected to analysis of variance and means were compared by Tukey test with $\mathrm{P}<0.05$, using the ASSISTAT 7.6 Beta (SILVA \& AZEVEDO, 2009 ).

\section{RESULTS AND DISCUSSION}

\section{Chemical attributes of the soil and drainage water}

The mechanical and chemical treatments used affected the soil chemical attributes $(\mathrm{P}<0.05)$. Although, no differences were observed in soil attributes when comparing crop rotation established with cotton/cowpea and sunflower/cowpea in 2010 (P> 0.05), but interaction between the factors of assessments was significant in 2011 ( $\mathrm{P}<0.05$ ), suggesting that in the medium to long term, changes in the soil chemical attributes depend not only on the applied products, but also the types of established crops in the area.

Comparing the values of $\mathrm{EC}_{1: 1}$ measured prior to beginning of the study ( $4.0 \mathrm{dS} \mathrm{m}^{-1}$, Table 1) and in 2010, almost a year after (Table 2), it is observed that there were reductions in all treatments applied highlighting the treatments $\mathrm{T} 1(\mathrm{~S})$ and $\mathrm{T} 2\left(\mathrm{SG}_{20}\right)$ for crop rotation $\mathrm{C} / \mathrm{CP}$ and $\mathrm{T} 5\left(\mathrm{SG}_{20} \mathrm{OM}_{40}\right)$ for crop rotation S/CP that showed reductions of 83.25, 79.75 and $76 \%$, respectively. It also appears that the values of $\mathrm{EC}_{1: 1}$ did not differ between reclamation treatments in 2010 (Table 2). 
TABLE 2. Mean values of electrical conductivity in 1:1 extract $\left(\mathrm{EC}_{1: 1}\right)$, exchangeable sodium percentage (ESP) and contents of calcium $\left(\mathrm{Ca}^{2+}\right)$ in the $0-30 \mathrm{~m}$ layer under different treatments of soil reclamation and cotton/cowpea $(\mathrm{C} / \mathrm{CP})$ and sunflower/cowpea $(\mathrm{S} / \mathrm{CP})$ crop rotation.

\begin{tabular}{ccccccc}
\hline Treatments * & \multicolumn{2}{c}{$\mathrm{EC}_{1: 1}\left(\mathrm{dS} \mathrm{m}^{-1}\right)$} & \multicolumn{2}{c}{$\mathrm{ESP}(\%)$} & \multicolumn{2}{c}{$\mathrm{Ca}\left(\mathrm{cmol}_{\mathrm{c}} \mathrm{dm}^{-3}\right)$} \\
\hline & $\mathrm{C} / \mathrm{CP}$ & $\mathrm{S} / \mathrm{CP}$ & $\mathrm{C} / \mathrm{CP}$ & $\mathrm{S} / \mathrm{CP}$ & $\mathrm{C} / \mathrm{CP}$ & $\mathrm{S} / \mathrm{CP}$ \\
\hline \multicolumn{7}{c}{ July $2010(\mathrm{after}$ the first cycle of crop rotation $)$} \\
$\mathrm{T} 1$ & $0.67 \mathrm{aA}^{* *}$ & $1.09 \mathrm{aA}$ & $23.25 \mathrm{aA}$ & $23.97 \mathrm{aA}$ & $6.85 \mathrm{bA}$ & $5.95 \mathrm{aA}$ \\
$\mathrm{T} 2$ & $0.81 \mathrm{aA}$ & $1.04 \mathrm{aA}$ & $8.65 \mathrm{bA}$ & $10.90 \mathrm{abA}$ & $13.40 \mathrm{aA}$ & $8.60 \mathrm{aA}$ \\
$\mathrm{T} 3$ & $0.93 \mathrm{aA}$ & $1.06 \mathrm{aA}$ & $15.77 \mathrm{abA}$ & $16.50 \mathrm{abA}$ & $10.30 \mathrm{abA}$ & $6.25 \mathrm{aA}$ \\
$\mathrm{T} 4$ & $1.06 \mathrm{aA}$ & $1.17 \mathrm{aA}$ & $13.00 \mathrm{abA}$ & $7.05 \mathrm{bA}$ & $12.32 \mathrm{aA}$ & $7.12 \mathrm{aA}$ \\
$\mathrm{T} 5$ & $0.92 \mathrm{aA}$ & $0.96 \mathrm{aA}$ & $9.72 \mathrm{abA}$ & $9.55 \mathrm{bA}$ & $13.00 \mathrm{aA}$ & $7.32 \mathrm{aA}$ \\
$\mathrm{CV}(\%)$ & 34.88 & 36.75 & 36.29 & 39.08 & 9.57 & 22.33 \\
\hline \multicolumn{7}{c}{ July $2011(\mathrm{after}$ the second cycle of crop rotation $)$} \\
$\mathrm{T} 1$ & $0.44 \mathrm{bA}$ & $0.42 \mathrm{cdA}$ & $19.46 \mathrm{aA}$ & $18.21 \mathrm{aA}$ & $7.76 \mathrm{bA}$ & $7.60 \mathrm{bA}$ \\
$\mathrm{T} 2$ & $0.38 \mathrm{bA}$ & $0.53 \mathrm{cA}$ & $5.09 \mathrm{bA}$ & $6.28 \mathrm{bA}$ & $7.20 \mathrm{bB}$ & $14.92 \mathrm{aA}$ \\
$\mathrm{T} 3$ & $0.98 \mathrm{aA}$ & $1.11 \mathrm{aA}$ & $18.83 \mathrm{aA}$ & $17.32 \mathrm{aA}$ & $10.50 \mathrm{abA}$ & $11.15 \mathrm{abA}$ \\
$\mathrm{T} 5$ & $0.80 \mathrm{aA}$ & $0.29 \mathrm{~dB}$ & $14.69 \mathrm{aA}$ & $7.28 \mathrm{bB}$ & $13.06 \mathrm{aA}$ & $10.45 \mathrm{bA}$ \\
$\mathrm{CV}(\%)$ & $0.29 \mathrm{bB}$ & $0.76 \mathrm{bA}$ & $5.29 \mathrm{bB}$ & $17.86 \mathrm{aA}$ & $13.26 \mathrm{aA}$ & $9.6 \mathrm{bB}$ \\
\hline
\end{tabular}

*T1. Only subsoiling, (S); T2. Subsoiling $+20 \mathrm{Mg} \mathrm{ha}^{-1}$ of gypsum $\left(\mathrm{SG}_{20}\right)$; T3. Subsoiling $+40 \mathrm{Mg} \mathrm{ha}^{-1}$ of organic matter $\left(\mathrm{SOM}_{40}\right)$; T4. Subsoiling $+10 \mathrm{Mg} \mathrm{ha}^{-1}$ of gypsum $+20 \mathrm{Mg} \mathrm{ha}^{-1}$ of organic matter $\left(\mathrm{SG}_{10} \mathrm{OM}_{20}\right)$; $\mathrm{T}$. Subsoiling $+20 \mathrm{Mg} \mathrm{ha}^{-1}$ of gypsum +40 $\mathrm{Mg} \mathrm{ha}{ }^{-1}$ of organic matter $\left(\mathrm{SG}_{20} \mathrm{OM}_{40}\right)$.

** Means followed by the same lowercase letters in the column and same capital letters in the line, for the same year, do not differ by Tukey test at the 0.05 level of probability.

With exception of T3-( $\left.\mathrm{SOM}_{40}\right)$, the values of $\mathrm{EC}_{1 ; 1}$ continued decreasing in 2011 highlighting the treatments $\mathrm{T} 5\left(\mathrm{SG}_{20} \mathrm{OM}_{40}\right)$ of the crop rotation $\mathrm{C} / \mathrm{CP}$ and $\mathrm{T} 4\left(\mathrm{SG}_{10} \mathrm{OM}_{20}\right)$ of the crop rotation S/CP, which showed reductions of 68.47 and $75.21 \%$, respectively, compared to results observed in 2010. The total rainfall occurred in the years $2010(413 \mathrm{~mm})$ and $2011(1,066 \mathrm{~mm})$ along with the practices of soil tillage (subsoiling, disking) employed at the beginning of the experiment and the installation of subsurface drainage system also contributed significantly to accelerate the dilution process and elimination of salts in the soil as can be confirmed by the control treatment in the two years of crop rotation. Regarding to the soil ESP, relative decrease $(32.1 \%)$ in the initial value was also found, mainly for treatments $\mathrm{T} 2\left(\mathrm{SG}_{20}\right), \mathrm{T} 4\left(\mathrm{SG}_{10} \mathrm{OM}_{20}\right)$ and $\mathrm{T} 5\left(\mathrm{SG}_{20} \mathrm{OM}_{20}\right)$ with values below $15 \%$ which is considered as a threshold for sodic and non sodic soil.

Comparing the values of $\mathrm{EC}_{1: 1}$ and ESP at the end of the two cycles of crop rotation, it appears that the values continued to decline in 2011, compared to 2010, except for treatment in which only organic matter was applied (Table 2). It is noteworthy that the levels of salts in cattle manure may have influenced the results where just apply this material. In general, treatments with application of organic matter alone were more effective in reducing the salinity and especially of sodium when associated with gypsum.

The exchangeable sodium percentage (ESP) showed significant reductions compared to initial value (Table 1), especially for treatments with gypsum (Table 2), highlighting the role of chemical and organic amendments. Generally, treatment $\mathrm{T} 2\left(\mathrm{SG}_{20}\right)$ proved to be more efficient to promote the reduction of exchangeable sodium in the soil reducing about $84 \%$ of ESP values, compared to the initial values with those observed at the end of two cycles of crop rotation. According to ARAUJO et al. (2011), applying $20 \mathrm{Mg} \mathrm{ha}^{-1}$ of gypsum and $40 \mathrm{Mg} \mathrm{ha}^{-1}$ of organic matter promoted reduction in of ESP in the first year, decreasing the value from $50 \%$ for convergent value of $2 \%$. The incorporation of gypsum results in improvements in chemical properties, reflecting a decrease in salinity and sodicity of soils, and physical characteristics, such as increase in macroporosity and hydraulic conductivity of the soil. TAVARES FILHO et al. (2012) also observed physical and 
chemical improvement when gypsum was used in the correction of saline-sodic soils in the irrigated area of Moxotó in the municipality of Ibimirim, PE.

Comparing the types of crop rotation in the two production cycles, it appears that the treatments T4 and T5 were the ones that showed effects on soil attributes on the type of species used as shown in Table 2. Overall, these results may be due to the improvement in soil permeability as a function of the crops in the area, associated with the decomposition of organic matter formed by the roots along with incorporation of crop residues of cowpea, occurred at intervals of cotton and sunflower crops. SADIQ et al. (2003) and CAVALCANTE et al. (2010) also observed improvements in physical and chemical soil attributes using the gypsum in the correction of a saline-sodic soil, cultivated with cotton varieties.

For the concentration of calcium opposite was found in comparison to the sodium, and the highest values were found for the treatments with gypsum applications and organic matter (Table 2). The treatments T5 $\left(\mathrm{SG}_{20} \mathrm{OM}_{40}\right)$ for crop rotation $\mathrm{C} / \mathrm{CP}$ with $13.26 \mathrm{cmol}_{\mathrm{c}} \mathrm{dm}^{-3}$ and T2 $\left(\mathrm{SG}_{20}\right)$ for crop rotation S/CP with $14.92 \mathrm{cmol}_{\mathrm{c}} \mathrm{dm}^{-3}$ in 2011 were those with the highest values. The results agree with several studies such as SALDANHA et al. (2007), who showed that application of gypsum causes increase in levels of exchangeable calcium in the soil layers. The values obtained for exchangeable calcium indicate that the amount of gypsum applied was appropriate to increase calcium levels in all treatments.

Water analysis of the lateral drains demonstrated the beneficial effect, especially the treatments containing gypsum in promoting leaching of $\mathrm{Na}^{+}$, given that their concentrations were significantly increased (Table 3), which was also confirmed by decreased levels of ESP shown in table 2. The highest concentration of $\mathrm{Na}^{+}$was observed in the drain water that corresponding to the treatment $\mathrm{T} 2\left(\mathrm{SG}_{20}\right)$ containing $20 \mathrm{Mg} \mathrm{ha}^{-1}$ of gypsum and the lowest concentration of this ion was observed in the treatment without gypsum. For $\mathrm{Ca}^{2+}$ the highest concentrations were observed in the $\mathrm{T} 2$ and T5 treatments. No differences was observed in relation to $\mathrm{K}^{+}$. Another important aspect is that the concentrations of $\mathrm{Na}^{+}$were also well above those observed for $\mathrm{K}^{+}$and $\mathrm{Ca}^{2+}$, reflecting the existence of the problem of sodicity in the area.

TABLE 3. Concentrations of $\mathrm{Na}^{+}, \mathrm{K}^{+}$and $\mathrm{Ca}^{2+}$ in the drainage water under different treatments of soil reclamation.

\begin{tabular}{|c|c|c|c|c|c|}
\hline \multirow{3}{*}{ Treatments $*$} & \multicolumn{4}{|c|}{ Collects } & \multirow{3}{*}{ Mean } \\
\hline & 1 & 2 & 3 & 4 & \\
\hline & \multicolumn{4}{|c|}{$\mathrm{Na}\left(\mathrm{mmol}_{\mathrm{c}} \mathrm{L}^{-1}\right)$} & \\
\hline T1 & 6.50 & 9.43 & 6.12 & 9.17 & $7.80 \mathrm{~b}^{* *}$ \\
\hline $\mathrm{T} 2$ & 24.50 & 24.72 & 18.40 & 22.50 & $22.53 \mathrm{a}$ \\
\hline $\mathrm{T} 3$ & 12.42 & 9.61 & 8.27 & 11.69 & $10.50 \mathrm{~b}$ \\
\hline $\mathrm{T} 4$ & 7.99 & 16.07 & 9.11 & 13.79 & $11.74 \mathrm{~b}$ \\
\hline $\mathrm{T} 5$ & 9.93 & 22.02 & 13.06 & 11.14 & $14.03 \mathrm{~b}$ \\
\hline \multicolumn{6}{|c|}{$\mathrm{Ca}\left(\mathrm{mmol}_{\mathrm{c}} \mathrm{L}^{-1}\right)$} \\
\hline $\mathrm{T} 1$ & 0.14 & 0.19 & 0.08 & 0.11 & $0.12 \mathrm{c}$ \\
\hline $\mathrm{T} 2$ & 0.19 & 0.37 & 0.33 & 0.24 & $0.28 \mathrm{a}$ \\
\hline T3 & 0.13 & 0.16 & 0.10 & 0.05 & $0.10 \mathrm{c}$ \\
\hline $\mathrm{T} 4$ & 0.20 & 0.28 & 0.11 & 0.12 & $0.17 \mathrm{bc}$ \\
\hline T5 & 0.29 & 0.42 & 0.30 & 0.15 & $0.28 \mathrm{a}$ \\
\hline \multicolumn{6}{|c|}{$\mathrm{K}\left(\mathrm{mmol}_{\mathrm{c}} \mathrm{L}^{-1}\right)$} \\
\hline $\mathrm{T} 1$ & 0.11 & 0.26 & 0.17 & 0.17 & $0.17 \mathrm{a}$ \\
\hline $\mathrm{T} 2$ & 0.14 & 0.21 & 0.12 & 0.12 & $0.14 \mathrm{a}$ \\
\hline T3 & 0.09 & 0.39 & 0.19 & 0.19 & $0.21 \mathrm{a}$ \\
\hline $\mathrm{T} 4$ & 0.08 & 0.21 & 0.15 & 0.15 & $0.15 \mathrm{a}$ \\
\hline $\mathrm{T} 5$ & 0.16 & 0.20 & 0.13 & 0.13 & $0.15 \mathrm{a}$ \\
\hline
\end{tabular}

* For identification of treatments see Table 2

** Means followed by the same letters in the column do not differ statistically by the Tukey test at the 0.05 level of probability. 
The incorporation of gypsum in soil showed greater efficiency in correcting the salinity and sodicity and such advantage resulted from the increased solubility of gypsum incorporated and therefore increase the efficiency of replacement of the exchangeable sodium. These results agree with SANTOS et al. (2005) when it comes to the efficiency of gypsum in the leaching of sodium on the soil.

\section{Yield of cotton, sunflower and cowpea}

The mechanical and chemical treatments did not affect the yield of cotton in two cycles of crop rotation $(\mathrm{P}>0.05)$, but significant effects $(\mathrm{P}<0.05)$ were observed for cowpea on both crops and sunflower in the 2010/2011 cycle.

Table 4 shows the grain yields of the three species in both production cycles. The productivity of cotton seeds was not influenced by the reclamation treatments nor between the years of cultivation, a result that differs from those found by SADIQ et al. (2003) using gypsum in the correction of a saline-sodic soil, cultivated with cotton varieties. These authors found a significant increase in the percentage of germination and yield of cotton bolls compared to treatment without gypsum. The non-occurrence of yield difference among treatments applied in this study may be explained by the fact the cotton plant, according to AYERS \& WESTCOT (1999), it is a tolerant crop to salinity/sodicity able to express all their productive potential with a value of electrical conductivity threshold of $7.7 \mathrm{dS} \mathrm{m}^{-1}$ in the saturation extract of soil and ESP up to $40 \%$. In the present study also no differences in cotton lint production were found in two cycles, with values ranging from 522.6 to $629.8 \mathrm{~kg} \mathrm{ha}^{-1}$.

TABLE 4. Yield of cotton, sunflower and cowpea under different treatments of soil reclamation and crop rotation, during two production cycles.

\begin{tabular}{ccccc}
\hline Treatments $^{*}$ & \multicolumn{4}{c}{ Productivity $\left(\mathrm{kg} \mathrm{ha}^{-1}\right)$} \\
\hline \multicolumn{2}{c}{ Cotton } & \multicolumn{2}{c}{ S010/2011 } & \multicolumn{2}{c}{ Sunflower } \\
\hline T1 & $1469.45 \mathrm{aA}^{* *}$ & $1285.15 \mathrm{aA}$ & $1991.25 \mathrm{aA}$ & $1625.93 \mathrm{bB}$ \\
T2 & $1175.78 \mathrm{aA}$ & $1415.04 \mathrm{aA}$ & $2092.50 \mathrm{aB}$ & $2561.62 \mathrm{abA}$ \\
T3 & $1326.76 \mathrm{aA}$ & $1319.33 \mathrm{aA}$ & $2145.00 \mathrm{aA}$ & $2466.75 \mathrm{abA}$ \\
T4 & $1267.66 \mathrm{aA}$ & $1421.87 \mathrm{aA}$ & $2175.00 \mathrm{aA}$ & $2501.25 \mathrm{abA}$ \\
T5 & $1391.25 \mathrm{aA}$ & $1360.35 \mathrm{aA}$ & $2647.50 \mathrm{aB}$ & $3044.62 \mathrm{aA}$ \\
& \multicolumn{2}{c}{ Cowpea } \\
T1 & $707.22 \mathrm{bA}$ & $646.54 \mathrm{bA}$ & $715.09 \mathrm{bA}$ & $641.07 \mathrm{bA}$ \\
T2 & $836.39 \mathrm{bA}$ & $1320.00 \mathrm{aA}$ & $649.07 \mathrm{bB}$ & $1321.00 \mathrm{aA}$ \\
T3 & $573.35 \mathrm{bB}$ & $1267.93 \mathrm{aA}$ & $898.08 \mathrm{bA}$ & $1202.40 \mathrm{aA}$ \\
T4 & $696.91 \mathrm{bB}$ & $1291.25 \mathrm{aA}$ & $736.65 \mathrm{bB}$ & $1291.26 \mathrm{aA}$ \\
T5 & $1480.91 \mathrm{aA}$ & $1276.99 \mathrm{aA}$ & $1409.82 \mathrm{aA}$ & $1276.78 \mathrm{aA}$ \\
\hline
\end{tabular}

* For identification of treatments see Table 2;

** Means followed the same lowercase letters in columns and capital letters in the lines, in the same year and for each species, do not differ by Tukey test at the 0.05 level of probability.

Sunflower yields did not suffer significant effects in the treatments in 2009/2010 (Table 4). However, for the year 2010/2011 were observed significant effects between treatments with and without gypsum, T1 and T5, respectively, with the highest yield observed in treatments which received applications of this amendment. Significant differences were also observed in sunflower yield between the years for T1, T2 and T5. For T2 and T5 increments were respectively of 22 and $15 \%$, while for $\mathrm{T} 1$ drop in the yield was observed, comparing the values of second with those of the first crop cycle. According to BATISTA et al. (2002) the sunflower crop has its maximum productivity up to ECs of $5.3 \mathrm{dS} \mathrm{m}^{-1}$ in the saturation extract of the soil. MORAIS et al. (2011) also observed similar results. 
For the cowpea in the year 2009/2010 the treatments T1 to T4 did not differ statistically (Table 4). However, the treatment $\mathrm{T} 5-\left(\mathrm{SG}_{20} \mathrm{OM}_{40}\right)$ resulted in higher productivity, reaching productivity twice as compared to the other treatments. The low productivity of $\mathrm{T} 1 \mathrm{can}$ be attributed to no application of gypsum and organic matter, whereas in T5 treatment this increase in production may have been influenced by a faster soil reaction occurred due to the greater amount of amandments incorporated. In the year 2010/2011 T1 (S) treatment that received only sub soiling showed lower yield than the others which did not differ among themselves. In the comparison between the two years of rotation, a substantial increase was observed in the production of cowpea in the second cycle, especially for treatments that received gypsum. Significant differences were observed for the T3 and T4 in the rotation $\mathrm{C} / \mathrm{CP}$ and $\mathrm{T} 2$ and $\mathrm{T} 4$ in the rotation S/CP. Overall there was a significant increase in the mean productivity of cowpea in 2010/2011 cycle in comparison with the cycle 2009/2010, which indicates a progressive reclamation of the soil. Apparently, the high rates of gypsum applied in the T5 treatment accelerated the reclamation process which resulted in higher yields of cowpea in the first cycle, compred to other treatments.

ARAUJO et al. (2011) obtained productivity of cowpea cv. Epace 11 with the application of organic matter and gypsum $120 \%$ higher than productivity without the use of these amendments, and only $18 \%$ lower yield in soil without problems of salts in the same region. SANTOS et al. (2009) working in areas without salinity problem obtained grain yield of $1,230 \mathrm{~kg} \mathrm{ha}^{-1}$ with the cv. Espace 10, indicating that the productivities obtained in the present study, in the second year of soil reclamation process, are compatible with those obtained in conditions of low salinity.

\section{CONCLUSION}

The use of chemical and organic amendments contribute to decrease levels of salinity and sodicity, being its most evident effects to reduce sodicity, with gypsum proving more efficient in this process.

The cotton showed no response to treatments, while the sunflower crop was favored by the application of gypsum only in the second production cycle.

The highest productivity of cowpea in $\mathrm{T} 5$ treatment (Sub soiling $+20 \mathrm{Mg} \mathrm{ha}^{-1}$ of gypsum +40 $\mathrm{Mg} \mathrm{ha}^{-1}$ of organic matter) in 2009/2010 cycle, are indicative of the large doses of gypsum and organic matter applied in this treatment accelerated the reclamation process. For other treatments with amendments, a beneficial effect was verified for this crop only in the second cycle of production, when the values were equal to T5 and were significantly higher than the first cycle.

The results of this study demonstrate that application of gypsum and organic products, combined with crop rotation systems using tolerant or moderately tolerant species, can technically enable the reclamation of salt affected soils.

\section{ACKNOWLEDGEMENTS}

The authors thank CNPq, the INCTSal and FUNCAP for financial support and the grant of scholarships.

\section{REFERÊNCES}

ARAÚJO, A. P. B.; COSTA, R. N. T.; LACERDA, C. F.; GHEYI, H. R. Análise econômica do processo de recuperação de um solo sódico no Perímetro Irrigado Curu-Pentecoste, CE. Revista Brasileira de Engenharia Agrícola e Ambiental, Campina Grande, v.15, n.4, p. 377-382, 2011.

ASHRAF, M. Biotechnological approach of improving plant salt tolerance using antioxidants as markers. Biotechnology Advances, Waterloo, v.27, p.84-93, 2009.

AYERS, R. S.; WESTCOT, D. W. A qualidade da água na agricultura. 1. ed. Campina Grande: UFPB, 1999. $218 \mathrm{p}$. 
BARROS, M. DE F. C.; BEBÉ, F. V.; SANTOS, T. O.; CAMPOS, M. C. C. Influência da aplicação de gesso para correção de um solo salino sódico cultivado com feijão caupi. Revista de Biologia e Ciências da Terra, Campina Grande, v.9, p.77-82, 2009.

BATISTA, M. J.; NOVAES, F.; SANTOS, D. G.; SUGUINO, H. H. Drenagem como instrumento de dessalinização e prevenção da salinização de solos. 2. ed. rev. e ampliada. Brasília:

CODEVASF, 2002. 216p.

BEZERRA, A. K. P.; LACERDA, C. F.; HERNANDEZ, F. F. F.; SILVA, F. B.; GHEYI, H. R. Rotação cultural feijão-de-corda/milho utilizando-se águas de salinidades diferentes. Ciência Rural, Santa Maria, v. 40, n. 5, p. 1075-1082, 2010.

CAVALCANTE, L. F.; SANTOS, R. V.; HERNANDEZ, F. F. F.; GHEYI, H. R.; DIAS, T. J. Recuperação de solos afetados por sais. In: GHEYI, H. R.; DIAS, N. S.; LACERDA, C. F. Manejo da salinidade na agricultura: Estudos básicos e aplicados. Fortaleza: INCTSal, 2010. p.425-448.

GALBIATTI, J. A.; LUI, J. J.; SABONARO, D. Z.; BUENO, L..; SILVA, V. L. Formação de mudas de eucalipto com utilização de lixo orgânico e níveis de irrigação calculados por dois métodos. Engenharia Agrícola, Jaboticabal, v. 27, n. 2, p. 445-455, 2007.

LACERDA, C. F.; SOUSA, G. G.; SILVA, F. L. B.; GUIMARÃES, F. V. A.; SILVA, G. L.; CAVALCANTE, L. F. Soil salinization and maize and cowpea yield in the crop rotation system using saline waters. Engenharia Agrícola, Jaboticabal, v. 31, p. 663-675, 2011.

LEAL, I. G.; ACCIOLY, A. M. A.; NASCIMENTO, C. W. A.; FREIRE, M. B. G. S.;

MONTENEGRO, A. A. A.; FERREIRA, F. L. Fitorremediação de solo salino sódico por Atriplex nummularia e gesso de jazida. Revista Brasileira de Ciência do Solo, Viçosa, MG, v.32, p.10651072, 2008.

LEITE, E. M.; CAVALCANTE, L. F.; DINIZ, A. A.; SANTOS, R. V.; ALVES, G. S.; CAVALCANTE, I. H. L. Correção da sodicidade de dois solos irrigados em resposta à aplicação de gesso agrícola. Irriga, Botucatu, v. 12, n. 2, p. 168-176, 2007.

LV, S.; ZHANG, K.; GAO, Q,; LIAN, L.; SONG, Y.;ZHANG, J. Over expression of an H+-PPase gene from Thellungiella halophila in cotton enhances salt tolerance and improves growth and photosynthetic performance. Plant \& Cell Physiology, Oxford, v. 49, n. 08, p. 1150-1164, 2008.

MELO, R. M.; BARROS, M. F. C.; SANTOS, P. M.; ROLIM, M. M. Correção de solos salinosódicos pela aplicação de gesso mineral. Revista Brasileira de Engenharia Agrícola e Ambiental, Campina Grande, v.12, p.376-380, 2008.

MIRANDA, M. A.; OLIVEIRA E. E. M.; SANTOS, K. C. F.; FREIRE, M. B. G. S.; ALMEIDA, B. G. Condicionadores químicos e orgânicos na recuperação de solo salino-sódico em casa de vegetação. Revista Brasileira de Engenharia Agrícola e Ambiental, Campina Grande, v.15, n.5, p. 484-490, 2011.

MIRANDA, M. F. A.; PESSOA, L. G. M.; FREIRE, M. B. G. S.; FREIRE, F. J. Correção de solo salino-sódico com soluções de cloreto de cálcio cultivado com sorgo sudanense. Caatinga, Mossoró, v.21, n.5, p.18-25, 2008.

MORAIS, F. A.; GURGEL, M. T.; OLIVEIRA, F. H. T.; MOTA, A. F. Influência da irrigação com água salina na cultura do girassol. Revista Ciência Agronômica, Fortaleza, v. 42, n. 2, p. 327-336, 2011.

MURTAZA, G.; GHAFOOR. A.; QADIR, M. Irrigation and soil management strategies for using saline-sodic water in a cotton-wheat rotation. Agricultural Water Management, Amsterdam, v.81, p. $98-114,2006$. 
RIBEIRO, M. R.; BARROS, M. F. C.; FREIRE, M. B. G. S. Química dos solos salinos e sódicos. In: MELO, V. F.; ALLEONI, L. R. Química e mineralogia do solo. Viçosa: Sociedade Brasileira de Ciência do Solo, 2009. v. 2, p.449- 484.

SADIQ, M.; HASSAN, G.; KHAN, A.G.; HUSSAIN, N.; JAMIL, M.; GOUNDAL, M. R.; SARFRAZ. M. Performance of cotton varieties in saline sodic soil amended with sulfuric acid and gypsum. Pakistan Journal of Agricultural Sciences, Faisalabad, v.40, n.3-4, p.99-105, 2003.

SALDANHA, E. C. M.; ROCHA, A. T.; OLIVEIRA, E. C. A.; NASCIMENTO, C. W. A.; FREIRE, F. J. Uso do gesso mineral em Latosssolo cultivado com cana de açúcar. Caatinga, Mossoró, v.20, n.1, p.36-42, 2007.

SANTOS, J. F. GRANGEIRO, J. I. T.; BRITO, C. H.; SANTOS, M. C. C. A. Produção e componentes produtivos de variedades de feijão caupi na microregião cariri paraibano. Revista Engenharia Ambiental, Espírito Santo do Pinhal, v. 6, n. 1, p. 214-222, 2009.

SANTOS M. F. G.; OLIVEIRA, F. A.; CAVALCANTE, L. F.; MEDEIROS, J. F.; SOUZA. C. C. Solo sódico tratado com gesso agrícola, composto de lixo urbano e vinhaça. Revista Brasileira de Engenharia Agrícola e Ambiental, Campina Grande, v.9 n.3, p.307-313, 2005.

SILVEIRA, K. R.; RIBEIRO, M. R.; OLIVEIRA, L. B.; HECK, R. J.; SILVEIRA, R. R. Gypsum saturated water to reclaim alluvial saline sodic and sodic soils. Scientia Agrícola, Piracicaba, v.65, p.69-76, 2008.

SILVA, F. A. S. E.; AZEVEDO, C. A. V. Principal components analysis in the software assistatstatistical attendance. In: WORLD CONGRESS ON COMPUTERS IN AGRICULTURE, 7., 2009, Procedings... Reno: American Society of Agricultural and Biological Engineers, 2009.

SMEDEMA, L. K.; SHIATI, K. Irrigation and salinity: a perspective review of the salinity hazards of irrigation development in the arid zone. Irrigation and Drainage Systems, Netherlands, v.16, n.2, p.161-74. 2002.

SOUZA, E. R.; FREIRE, M. B. G. S.; NASCIMENTO, C. W. A.; MONTENEGRO, A. A. A.; FREIRE, F. J.; MELO, H. F. Fitoextração de sais pela Atriplex nummularia lindl.sob estresse hídrico em solo salino sódico. Revista Brasileira de Engenharia Agrícola e Ambiental, Campina Grande, v.15, n.5, p. 477-483, 2011.

TAVARES FILHO, A. N.; BARROS, M. F. C.; ROLIM, M. M.; SILVA, Ê. F. F. Incorporação de gesso para correção da salinidade e sodicidade de solos salino-sódicos. Revista Brasileira de Engenharia Agrícola e Ambiental, Campina Grande, v.16, n.3, p. 247-252, 2012. 